\title{
GROUNDWATER CONSERVATION ATTITUDES, BEHAVIOUR AND WATER MANAGEMENT: THE CASE OF FARMERS IN RURAL INDIA
}

\author{
MARIA E. VARUA ${ }^{1}$, BASANT MAHESHWARI ${ }^{1}$, JOHN WARD $^{2} \&$ SEEMA DAVE $^{1}$ \\ ${ }^{1}$ Western Sydney University, Australia \\ ${ }^{2}$ Mekong Region Futures Institute, Laos
}

\begin{abstract}
Due to the problem of groundwater availability in many locations across India in recent years, there has been a recent focus on understanding the attitudes and practices of rural farmers in enhancing water conservation practices. Farmer's positive or negative attitudes about groundwater conservation practices can affect their behaviours about adoption of water conservation practices. The aim of this study is to provide much-needed empirical data about rural farmers' attitudes towards ground water conservation, and their water conservation behaviours. Results from a survey of 759 farmers indicate that Indian farmers generally have very positive attitudes towards groundwater conservation and water saving practice. The main factors influencing the conservation behaviours identified in the study are: size of land holding, educational level, off-farm income, and environmental values. These findings highlight the fact that there is still substantial potential to be harvested in India though ground water conservation measures.
\end{abstract}

Keywords: groundwater conservation, attitudes, environmental values, MAR, socio-demographic characteristics.

\section{INTRODUCTION}

Groundwater is a vital natural resource needed for multiple uses such as drinking, irrigation, washing, cleaning and also critical to the normal functioning of ecosystems. In India, groundwater is a significant source of irrigation and accounts for more than half of net irrigated area in the country [1]. Most importantly, it is a source of drinking water and irrigation to the arid and semi-arid areas which are characterised by insufficient rainfall and low productivity. Almost 53.4\% of India's total land area is described as arid and semi-arid and these areas are facing several challenges including: declining groundwater levels, land degradation, limited livelihood opportunities, and poverty.

Despite past efforts to improve the sustainability of groundwater in India, the problem of groundwater extractions exceeding recharge remains severe. There are several reasons that may help explain this phenomenon. One of these is the increased access to groundwater has since the 1970s, when diesel and electric pumps became affordable to most small land holders. Also, the government schemes subsidising rural electricity, initially introduced as a poverty alleviation mechanism, have meant well owners are subject to set annual fees in contrast to metred usage [2]. In addition, there is also the rapid increase in population and economic growth. Other believe that the adoption of high yielding crop varieties and increased cropping intensity to meet food demands and livelihood improvement have resulted in escalated pressure on groundwater resources in most parts of India. Further, the dependence on groundwater resources has substantially increased due to the increased scarcity of surface water and variance of monsoon patterns, particularly the arid and semiarid regions [3]. Likewise, the increase in competition for water from non-agricultural uses, particularly urban water supplies and industries [4] has led to over exploitation of groundwater resources resulting in escalating rates of water table decline predominantly in Punjab, Haryana, Gujarat and Rajasthan. On top of that, climate change effects are worsening 
the existing problems as rising temperatures increases evaporation resulting in further increases in demand for energy and groundwater water in agriculture.

Taking into account the existing and future challenges faced by semi-arid areas, the central and state governments of India initiated Community based Natural Resource Management (CNRM) programmes like Watershed Development (WDP), and social welfare schemes like the National Rural Employment Guarantee Act, 2005 (NREGA) in early 1990s primarily aimed to sustainably manage natural resources and reduce poverty. The Watershed Development and NREGA are the biggest programmes in terms of coverage, investment and dedicated administrative staff on the ground. The land and water conservation plans conducted under these programmes lead to the establishment Management of Aquifer Recharge (MAR) projects. Moreover, many NGOs are putting significant efforts to adopt MAR by promoting it via agriculture extension, watershed development, and participatory groundwater management in different parts of India.

The gravity of groundwater scarcity problems across India has necessitated the need for alternative solutions, both technological and behavioural. Water conservation through MAR, efficient watering and farm water harvesting are emerging as important avenue through which groundwater can be efficiently used. Behavioural change towards water conservation and public acceptance of conservation initiatives remain critical. Although many studies have investigated socio-demographic characteristics and groundwater use, little is known about the relationship between general environmental values and water conservation attitudes and behaviour. The aim of this paper is to fill this gap by examining rural farmers' attitudes towards groundwater conservation in Gujarat and Rajasthan. Also, the study aims to determine factors affecting farmers' decision making on adoption of groundwater conservation practices.

The rest of the paper is organised as follows. Section 2, presents a summary of the literature relevant to the current study while Section 3 describes the methodological framework including the study area and the characteristics of the respondents. In Section 4, the results are presented and the conclusions and recommendations are summarised in Section 5 .

\section{LITERATURE REVIEW}

The success of groundwater conservation program requires the understanding of various aspects of farmers' behaviour as their behaviour is the result of their attitude about the conservation of groundwater. Farmers' positive or negative attitudes about groundwater conservation practices can affect their behaviours about the adoption of groundwater conservation practices. Many of the studies to test public attitudes toward the environment used sociological and psychological approaches, and included socio-economic and demographic indicators to explain environmental attitudes or concern [5].

\subsection{Socio-demographic indicators}

A number of studies have reported significant relationships between income, gender, and education on environmental attitudes and conservation behaviour [6]. Similarly, several others studied relationships between water conservation behaviour and socio-demographic variables such as income, education and political views. While some researchers found that conservation attitudes have a positive correlation with income and education, others found an inverse relationship [7]. Gender has also been identified to be associated with proenvironmental behaviour with most of the studies predicting that women are more inclined towards environmentally friendly behaviour [8]. 
In a study on barriers to irrigation water conservation in the Rio Grande Basin, the researchers identified the important barriers to include: land owning type, attitude towards conservation, incorrect water conservation programs, limitations of water transfers, and unclear functions of water [9].

\subsection{Personal values}

In psychology, the starting point of value research has essentially been the purpose that values actually serve. Past studies reviewed indicated that a number of values (particularly those pertaining to the environment and personal wealth and family) were weakly but positively related to both conservation behaviour and beliefs about the efficacy and necessity of conservation [10], [11]. Some studies also argue that values influenced behavioural commitment independently of person and contextual factors, but did not predict such behaviour above and beyond these other factors. Furthermore, others concluded that personal values do not exert a major impact on personal commitment to conserve and therefore do not constitute a significant obstacle to such efforts [12].

\section{MATERIALS AND METHODS}

\subsection{Study area}

The reported research was conducted in the Meghraj watershed in Aravalli district, Gujarat, and the Dharta watershed in Udaipur district, Rajasthan located in India. Both watersheds have a semi-arid climate, with an average annual rainfall in excess of $600 \mathrm{~mm}$, with more than $90 \%$ of this rainfall received only during the monsoon months of June to September. Most farmers in the two watersheds grow maize, black gram, mung bean, guar, soybeans (recently introduced) and vegetables as Kharif crops during the rainy season. Wheat, gram and mustard are the main Rabi crops grown during the winter season. Farmers who have access to groundwater (and in some instances canal water) grow two crops a year and those who have access to water supplies throughout the year also grow some summer crops such as vegetables and fodder.

The occurrence and distribution of rainfall in both the Meghraj and Dharta watersheds are highly uneven in both time and space. Kharif crops are mainly dependent on the vagaries of the monsoon and are often at risk of either complete or partial crop failure due to inadequate rainfall, or rainfall not occurring at a critical stage of crop growth. Therefore, the uneven and erratic distribution of rainfall provides a major challenge to growing crops successfully and to sustaining a decent livelihood. When rainfall does not occur at the right time or in the required amount some supplementary irrigation, also called 'life saving irrigation', using rainwater stored on the surface or drawn from the underground aquifer systems can make a substantial difference in avoiding crop failure.

It is important to note that both watersheds are in hard rock aquifer areas. It is well known that hard rock aquifers have low porosity and low connectivity and the movement of groundwater occurs through faults, fissures and fractures. Hence, they store limited volumes, and when stored water is withdrawn by pumps, the emptied pores are not immediately filled by flows from adjacent areas. As a result of low rain-recharge, and low porosity and low connectivity, the depth to water table fluctuates considerably during the year and significant water scarcity is often experienced during summer months or drier years. 


\subsection{Survey design}

The data utilised in this study comes from the survey data conducted by the Managing Groundwater Use and Aquifer Recharge through Village-level Intervention (MARVI) research team. The project is funded by Australian Centre for Agricultural Research (ACIAR) and is examining how the engagement of village communities and other stakeholders and the understanding of groundwater science can be integrated to improve the availability of water for crop production in the longer-term and increase livelihood opportunities for farmers. The project has involved socio-economic and cultural understanding of groundwater issues and challenges and monitoring of water table, rainfall, water levels in check dams as well as field trials to identify water saving practices in selected watersheds in Rajasthan and Gujarat states.

Samples of 759 randomly selected farmers were surveyed through face to face interviews. The results from 759 respondents (500 in Gujarat and 249 in Rajasthan) are reported in this analysis. Four field enumerators conducted the survey in Gujarat and five enumerators were engaged to conduct the survey in Rajasthan. The questionnaires were translated into the local dialect in order to construct clear, direct questions and promote consistent interviewee.

To check the reliability of the survey questionnaire, the Cronbach's alpha statistic was calculated and found to be approximately 0.87 , indicating valid reliability. Descriptive statistics, frequency distribution, correlation tests were used for data analysis. Statistical Package for Social Sciences (SPSS) was used to analyse the data.

\subsection{Data, description of variables, summary statistics}

In India, the total number of mechanised wells and tube wells rose from less than a million in the 1960 to estimated 21 million in 2002 [2]. As a consequence, India now withdraws some 230 billion $\left(10^{9}\right)$ cubic meters of groundwater per year [18] to provide additional irrigation to 45 million hectares of gross cropped area. Hence, competition by individual well owners to compensate depleted ground water levels relied on deploying high horse power submersible pump sets, accelerating water table decline and the emergence of a groundwater elite. In recent years, the Indian government implemented conservation programs to address the issue of declining groundwater availability however the reversal has not happened quick enough for the farmers not to worry. Understanding the nature of decision making by farmers considering trade-off between financial motivations and conservation is important.

Farmers' attitudes were measured using specific questions summarised in Table 1. For some of these questions, farmers responded with "yes" or "no" answer to indicate whether they agree or not with the statement. For other questions, they have to indicate their current practice.

Table 1 indicates that around $45 \%$ of farmers in Gujarat and $47 \%$ of farmers in Rajasthan agreed that MAR is the best way to maintain their wells. The results also indicate that approximately $75 \%$ and $49 \%$ of the respondents in Gujarat and Rajasthan respectively were in agreement that efficient use of water is the best way to maintain their wells. When asked whether they would reduce the number of watering they do if it meant that water will be assured for your children an overwhelming majority of respondents (72\% Gujarat and $67 \%$ Rajasthan) indicated that they will. However, only $20 \%$ of farmers in Gujarat and $11 \%$ of those in Rajasthan used mulching as a way to conserve water. Likewise, a small percentage of farmers (23\% in Gujarat and $5 \%$ in Rajasthan) employed farm water harvesting. Interestingly, the majority of farmers in Gujarat engage in traditional tillage while many of 
Table 1: Summary of farmers' conservation attitude and practice (in \%).

\begin{tabular}{|l|c|c|c|c|}
\hline \multirow{2}{*}{ Question/Item } & \multirow{2}{*}{ Response } & \multicolumn{2}{|c|}{ District } & \multirow{2}{*}{ Total } \\
\cline { 3 - 4 } & Gujarat & Udaipur & \\
\hline $\begin{array}{l}\text { Is MAR the best way to maintain } \\
\text { your well? }\end{array}$ & yes & 44.60 & 47.39 & 45.53 \\
\hline $\begin{array}{l}\text { Is efficient water use the best way to } \\
\text { maintain your well? }\end{array}$ & yes & 74.80 & 48.59 & 66.09 \\
\hline $\begin{array}{l}\text { Would you be willing to reduce the } \\
\text { number of watering if it meant that } \\
\text { water would be assured for your } \\
\text { children? }\end{array}$ & yes & 72.60 & 67.47 & 70.89 \\
\hline $\begin{array}{l}\text { Would you be willing to adopt a new } \\
\text { groundwater management scheme } \\
\text { that shared water and costs fairly } \\
\text { amongst all irrigators in your } \\
\text { village? }\end{array}$ & yes & 95.00 & 70.28 & 86.78 \\
\hline Mulch as water conservation & yes & 20.60 & 11.24 & 17.49 \\
\hline Farm water harvesting & yes & 22.60 & 4.42 & 16.56 \\
\hline $\begin{array}{l}\text { Tillage practice } \\
\text { Land }\end{array}$ & minimum & 33.20 & 65.06 & 43.79 \\
\hline & traditional & 66.80 & 34.54 & 56.07 \\
\hline Land levelling & yes & 17.40 & 16.06 & 16.96 \\
\hline Soil improvement & 92.40 & 90.76 & 91.86 \\
\hline
\end{tabular}

the farmers in Rajasthan practiced minimum tillage. Yet in both locations only a handful of farmers used land levelling. Soil improvement in both sites is normally done by the use of manure.

As indicated in Section 2, there are several socio-demographic variables that are highly correlated with farmers' adaption of water saving practices. Table 2 identifies some of the socio-demographic variables included in the study. The summary statistics shows that majority of the respondents were male with $88 \%$ in Gujarat and $97 \%$ in Rajasthan. Further, many of the respondents were 35 years old or older $(85 \%$ in total) and were not members of any type of community association ( $87 \%)$. The actual age class used in the analysis have nine (9) classes.

Around $72 \%$ of farmers in Gujarat belonged to schedule tribal group while $64 \%$ of those in Rajasthan belonged to the general group. Also, during the interview farmers were asked to response to a number of hypothetical scenarios and from their responses a cluster analysis was undertaken to identify the different types of adapters. Table 2 shows that $68 \%$ of farmers in Gujarat were very low adapters while $51 \%$ of farmers in Rajasthan were identified as very high adapters. When it comes to farm size, farmers in Gujarat were likely to have smaller land holdings compared to Rajasthan farmers. 
Table 2: Selected socio-demographic characteristics of farmers (in \%).

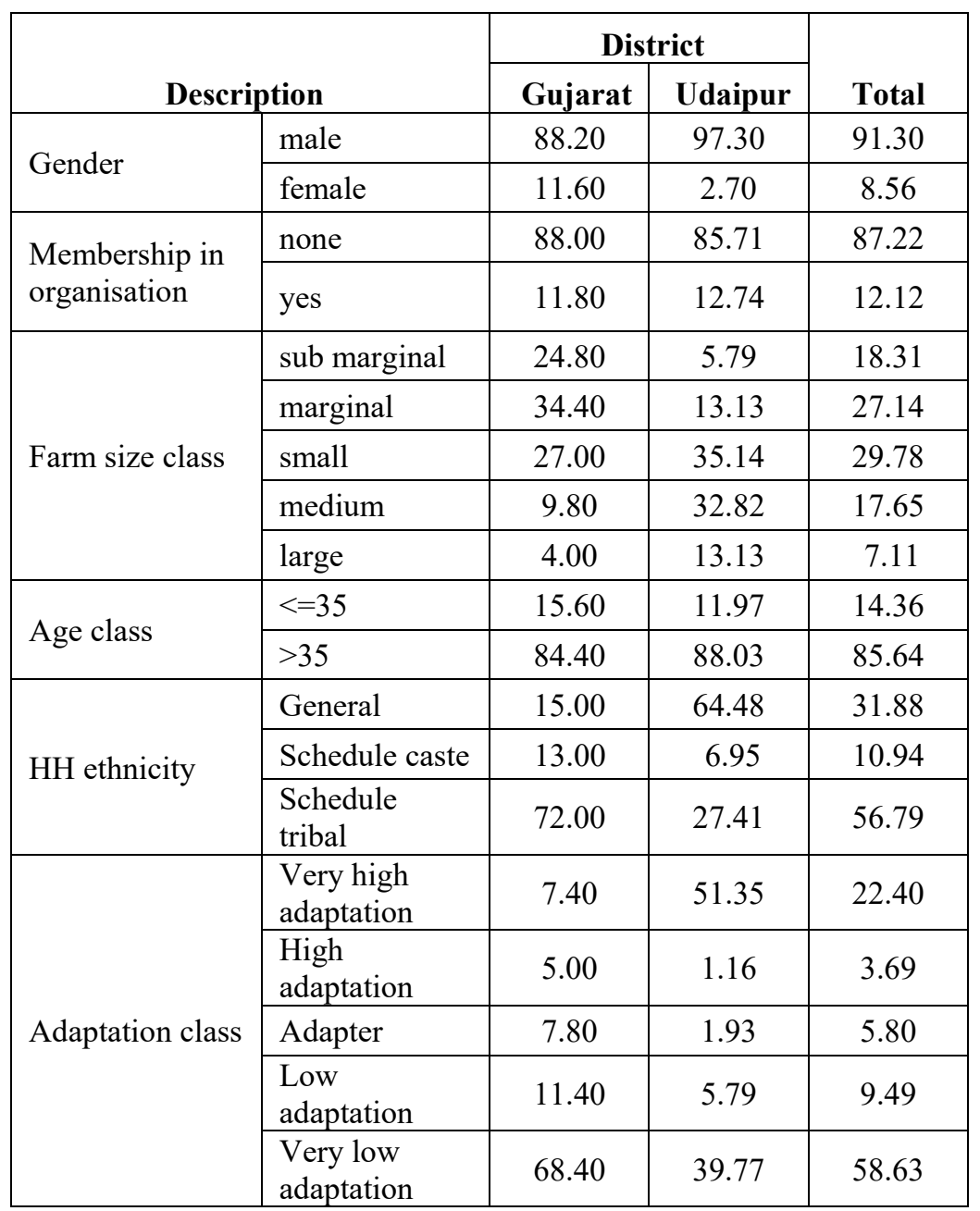

\section{RESULTS}

\subsection{Relationship between selected attributes and farmers' groundwater attitudes}

The correlations between selected quantitative variables were estimated by the Pearson test. Table 3 reveals that household (HH) income level is not related to farmers' attitudes on MAR, efficient water use and mulching but a significant positive relationship with the practice of farm water harvesting $(\mathrm{r}=0.788)$. On the other hand, test results obtained reveal that off farm income is significantly associated with MAR, efficient water use and farm harvesting. However, an inverse relationship is noted between HH Income and MAR. This finding is different from the findings for the paddy farmers of Iran [13] where they found a strong positive correlation between total household income and grower's attitude towards water and soil conservation. 
Table 3: Results of correlation test of farmers' attitudes towards groundwater conservation.

\begin{tabular}{|c|c|c|c|c|c|}
\hline Variable & Test & MAR & $\begin{array}{l}\text { Efficient } \\
\text { water use }\end{array}$ & $\begin{array}{l}\text { Farm water } \\
\text { harvesting }\end{array}$ & Mulching \\
\hline $\begin{array}{l}\mathrm{HH} \\
\text { income } \\
\text { level }\end{array}$ & $\begin{array}{l}\text { Spearma } \\
\mathrm{n}\end{array}$ & $\begin{array}{l}0.050 \\
(0.170) \\
\end{array}$ & $\begin{array}{l}0.000 \\
(0.990) \\
\end{array}$ & $\begin{array}{l}0.788 \\
(0.000) * * *\end{array}$ & $\begin{array}{l}0.018 \\
(0.626) \\
\end{array}$ \\
\hline $\begin{array}{l}\text { Off-farm } \\
\text { income }\end{array}$ & Pearson & $\begin{array}{l}-0.075 \\
(0.039) * *\end{array}$ & $\begin{array}{l}0.212 \\
(0.000) * * *\end{array}$ & $\begin{array}{l}0.012 \\
(0.071) *\end{array}$ & $\begin{array}{l}0.105 \\
(0.004)\end{array}$ \\
\hline $\begin{array}{l}\text { Farm } \\
\text { income }\end{array}$ & Pearson & $\begin{array}{l}-0.005 \\
(0.883)\end{array}$ & $\begin{array}{l}-0.036 \\
(0.318)\end{array}$ & $\begin{array}{l}-0.002 \\
(0.957)\end{array}$ & $\begin{array}{l}0.031 \\
(0.395)\end{array}$ \\
\hline $\begin{array}{l}\text { Age } \\
\text { classes }\end{array}$ & $\begin{array}{l}\text { Spearma } \\
\mathrm{n}\end{array}$ & $\begin{array}{l}-0.070 \\
(0.053) *\end{array}$ & $\begin{array}{l}-0.003 \\
(0.932)\end{array}$ & $\begin{array}{l}-0.132 \\
(0.000) * * *\end{array}$ & $\begin{array}{l}0.018 \\
(0.626)\end{array}$ \\
\hline Gender & $\chi^{2}$ & $\begin{array}{l}0.068 \\
(0.063) *\end{array}$ & $\begin{array}{l}-0.061 \\
(0.095) *\end{array}$ & $\begin{array}{l}0.030 \\
(0.418)\end{array}$ & $\begin{array}{l}0.059 \\
(0.109)\end{array}$ \\
\hline $\begin{array}{l}\text { Education } \\
\text { level }\end{array}$ & $\begin{array}{l}\text { Spearma } \\
\mathrm{n}\end{array}$ & $\begin{array}{l}0.640 \\
(0.076) *\end{array}$ & $\begin{array}{l}0.086 \\
(0.018) * *\end{array}$ & $\begin{array}{l}0.005 \\
(0.179)\end{array}$ & $\begin{array}{l}0.052 \\
(0.156)\end{array}$ \\
\hline HH size & Pearson & $\begin{array}{l}-0.058 \\
(0.044) * *\end{array}$ & $\begin{array}{l}0.002 \\
(0.932)\end{array}$ & $\begin{array}{l}0.059 \\
(0.109)\end{array}$ & $\begin{array}{l}0.041 \\
(0.268)\end{array}$ \\
\hline $\begin{array}{l}\text { Farm size } \\
\text { class }\end{array}$ & $\begin{array}{l}\text { Spearma } \\
\mathrm{n}\end{array}$ & $\begin{array}{l}0.032 \\
(0.037) * *\end{array}$ & $\begin{array}{l}0.009 \\
(0.983) \\
\end{array}$ & $\begin{array}{l}0.072 \\
(0.048) * *\end{array}$ & $\begin{array}{l}0.017 \\
(0.635) \\
\end{array}$ \\
\hline $\begin{array}{l}\text { Adaption } \\
\text { class }\end{array}$ & $\chi^{2}$ & $\begin{array}{l}0.089 \\
(0.014) * *\end{array}$ & $\begin{array}{l}0.143 \\
(0.000) * * *\end{array}$ & $\begin{array}{l}0.051 \\
(0.016) * *\end{array}$ & $\begin{array}{l}0.037 \\
(0.209)\end{array}$ \\
\hline Ids cluster & $\chi^{2}$ & $\begin{array}{l}-0.065 \\
(0.073) *\end{array}$ & $\begin{array}{l}-0.062 \\
(0.089) *\end{array}$ & $\begin{array}{l}-0.208 \\
(0.000) * * *\end{array}$ & $\begin{array}{l}-0.059 \\
(0.100) *\end{array}$ \\
\hline Ethnicity & $\chi^{2}$ & $\begin{array}{l}0.051 \\
(0.063) *\end{array}$ & $\begin{array}{l}0.117 \\
(0.001) * * *\end{array}$ & $\begin{array}{l}0.070 \\
(0.056) *\end{array}$ & $\begin{array}{l}0.010 \\
(0.784)\end{array}$ \\
\hline
\end{tabular}

$* * *, * *, *-$ significant at $1 \%, 5 \%$ and $10 \%$ respectively. $(\mathrm{xx})-p$-values.

The relationship between ordinal variables was evaluated using the Spearman test. For example, there were nine age groupings used in this study and when evaluated found not to be associated with conservation attitudes of MAR, efficient water use and the practice of mulching. Conversely, age is strongly negatively related to water harvesting. This result is in line with human capital theory which suggests that young farmers are expected to have a greater chance of applying new knowledge [14] such as water harvesting. Farmers' education level is highly positively correlated to farmers' attitudes on water conservation but not on their actual behaviour. In most adoption studies [15] farmers with higher levels of educational attainment are expected to adopt new technologies or practices than less educated farmers. 
Unlike previous studies, HH size was only related to MAR attitudes. Adaption attitude was found to be strongly positively correlated will both water conservation attitude and behaviour.

Index of Dissatisfaction (IDS) groupings were determined using the cluster analysis. In the questionnaire, respondents were asked to identify eight 8 factors that they are most concern about and to specify their relative importance to them. The answers were then converted to dissatisfaction index [16]. Three (3) distinct clusters were identified namely: economic, social and environment. Furthermore, the revealed a positive, significant relationship between IDS clusters and groundwater conservation attitudes and behaviours at $90 \%$ confidence interval. Finally, ethnicity was found to be inked with MAR, attitude of efficient water use and farm water harvesting.

\subsection{Values and farmers' groundwater attitudes}

The MARVI questionnaire included questions on personal values. For this study, five (5) of these values were chosen. For each of these questions, they were asked to indicate how important each value is for you as a guiding principle in your life. The rating scale used is defined as follows: (-1) opposed to my values; (0) means that it is not at all important in conducting your life; $(1,2,3)$ means the value is of increasing importance and (4) means that it is of supreme importance in your life.

To assess the relationship between the values and the conservation attitudes and behaviour, spearman tests were carried out. The results are summarised in Table 4. According to the value-belief norm theory developed from Schwartz's norm-activation theory [17], when individuals believe that environmental conditions threaten things they value and that they can act to reduce the threat, personal norms of a sense of obligation to take pro-environmental actions will be activated, and pro-environmental actions can happen. Table 4 reveals that environmental values were correlated with groundwater attitudes and behaviour. Similarly, wealth (material possessions and money) and family security (safety for loved ones) were found to be associated with groundwater conservation attitude and behaviour.

Table 4: Results of tests between values and farmers' attitudes towards groundwater conservation.

\begin{tabular}{|c|c|c|c|c|c|}
\hline Values & Test & MAR & $\begin{array}{l}\text { Efficient } \\
\text { water use }\end{array}$ & $\begin{array}{l}\text { Farm water } \\
\text { harvesting }\end{array}$ & Mulching \\
\hline $\begin{array}{l}\text { Respecting the } \\
\text { earth }\end{array}$ & Spearman & $\begin{array}{l}0.095 \\
0.009 * * *\end{array}$ & $\begin{array}{l}0.021 \\
0.057^{*}\end{array}$ & $\begin{array}{l}0.046 \\
0.216 \\
\end{array}$ & $\begin{array}{l}-0.030 \\
0.383 \\
\end{array}$ \\
\hline $\begin{array}{l}\text { Unity with } \\
\text { nature }\end{array}$ & Spearman & $\begin{array}{l}0.109 \\
0.004 * * *\end{array}$ & $\begin{array}{l}0.033 \\
0.074 * \\
\end{array}$ & $\begin{array}{l}-0.122 \\
0.001 * * *\end{array}$ & $\begin{array}{l}-0.170 \\
0.000 * * *\end{array}$ \\
\hline $\begin{array}{l}\text { Protecting the } \\
\text { environment }\end{array}$ & Spearman & $\begin{array}{l}0.094 \\
0.010 * * *\end{array}$ & $\begin{array}{l}0.026 \\
0.047 * *\end{array}$ & $\begin{array}{l}0.067 \\
0.069^{*}\end{array}$ & $\begin{array}{l}0.086 \\
0.020 * *\end{array}$ \\
\hline Wealth & Spearman & $\begin{array}{l}-0.191 \\
0.000 * * *\end{array}$ & $\begin{array}{l}0.262 \\
0.000 * * *\end{array}$ & $\begin{array}{l}0.065 \\
0.078^{*}\end{array}$ & $\begin{array}{l}0.091 \\
0.013 * * \\
\end{array}$ \\
\hline Family security & Spearman & $\begin{array}{l}0.096 \\
0.009 * * *\end{array}$ & $\begin{array}{l}0.015 \\
0.688 \\
\end{array}$ & $\begin{array}{l}-0.019 \\
0.600 \\
\end{array}$ & $\begin{array}{l}0.106 \\
0.004 * * *\end{array}$ \\
\hline
\end{tabular}

$* * *, * *, *-$ significant at $1 \%, 5 \%$ and $10 \%$ respectively. 


\section{CONCLUSIONS AND RECOMMENDATIONS}

The study highlighted he fact that farmers had positive attitudes towards groundwater conservation (see Table 1) which implies their interest for fulfilling groundwater conservation practices in their farms. The results further reveal that socio-demographic variables were related to groundwater attitude and behaviour (see Table 3). Farmer's educational level had a positive, significant relationship with their attitude and behaviour towards groundwater conservation, indicating that as their educational level increases, they attempt harder to protect the groundwater resource. In addition, the results indicate that farmers that are pro-environmental also see the need for groundwater conservation (see Table 4), and therefore consider it as an important aspect of environmental protection and stewardship.

Based on this study, the key factors that drive farmers to conserve groundwater turned out not only to be the socio-demographic characteristics of farmers as generally posited in groundwater conservation literature but also environmental values. Initiatives that influence farmers to use recharge (MAR) and groundwater efficiently are critical steps toward groundwater conservation, but must take into account farmers' general concern about the environment in addition to incorporating the current understanding of what sociodemographic factors drive farmers to conserve groundwater.

\section{REFERENCES}

[1] Dains, S.R. \& Pawar, J.R., Economic returns to irrigation in India. Report prepared by SDR Research Groups Inc., for the US Agency for International Development, New Delhi, 1987.

[2] Shah, T., Bhatt, S., Shah, R., \& Talati, J., Groundwater governance through electricity supply management: Assessing an innovative intervention in Gujarat, western India. Agricultural Water Management, 95(11), pp. 1233-1242, 2008, Online. http://impact.cgiar.org/pdf/215.pdf. Accessed 30 May 2017.

[3] Sakthivadivel, R., The groundwater recharge movement in India. The Agricultural Groundwater Revolution: Opportunities and Threats in Development, M. Giordano, K.G. Villoth, eds, CAB International. pp. 195-210, 2007.

[4] Lal, R., Tragedy of the Global Commons: Soil, Water and Air. Climate Change, Intercropping, Pest Control and Beneficial Microorganisms, Sustainable Agriculture Reviews 2, E. Lichtfouse, ed., Springer Science and Business Media, 2009.

[5] Dunlap, R.E. \& Van Liere, K.D., The New Environmental Paradigm. The Journal of Environmental Education, 40(1), pp. 19-28, 2008.

[6] Hamilton, L.C., Saving water: a casual model of household conservation. Sociological Perspectives, 26(4), pp. 355-374, 1983.

[7] Gilg, A. \& Barr, S., Behavioural attitudes towards water saving? Evidence from a study of environmental actions. Ecological Economics, 57(3), pp. 400-414, 2006.

[8] Kollmuss, A. \& Agyeman, J., Mind the gap: why do people act environmentally and what are the barriers to pro-environmental behaviour? Environmental Education Research, 8(3), pp. 239-260, 2002.

[9] Ward, F.A., Michelsen, A.M. \& DeMouche, M., Barriers to water conservation in the Rio Grande Basin. Journal of the American Water Resources Association, 43, pp. 237353, 2007.

[10] Stern, P.C., Dietz, T. \& Kalof, L., Value orientations, gender and environmental concern. Environment and Behavior, 25(5), pp. 322-348.

[11] Neuman, K., Personal Values and Commitment to Energy Conservation. Environment and Behavior, 18, pp. 53-74, 1986. 
[12] Dunlup, R., Grieneeks, J. \& Rokeac, H., Human values and 'proenvironmental' behaviour. Energy and Material Resources: Attitudes, Values, and Public Policy, W.D. Conn (ed.), Westview Press: Boulder, CO, 1983.

[13] Ashoori, D., Bagheri, A., Allahyari, M.S. \& Michailidis, A., Understanding the attitudes and practices of paddy farmers for enhancing soil and water conservation in Northern Iran. International Soil and Water Conservation Research, 4, pp. 260-266, 2016.

[14] Sidibe, M., Farm level adoption of soil and water conservation techniques in northern Bukina Faso. Agricultural Water Management, 71, pp. 177-196, 2005.

[15] Ramji, P., Neupane, K. \& Sharma, G.B.T., Adoption of agroforestry in the hills of Nepal: a logistic regression analysis. Agricultural Systems, 72, pp. 177-196, 2002.

[16] Larson, S., Regional well-being in tropical Queensland, Australia: developing a dissatisfaction index to inform government policy. Environment and Planning, 42(12), p. 2972, 2010.

[17] Schwartz, S.H., Normative explanations of helping behaviour: a critique, proposal, and empirical tests. Journal of Experimental Social Psychology, 9, pp. 349-364, 1973. 